Original Article

\title{
Non-Status Epilepticus female rats show seizure-like behaviors in the chronic phase of Pilocarpine experimental model
}

\author{
Ratas sem Status Epilepticus apresentam comportamento do tipo crise epiléptica na \\ fase crônica do modelo experimental da Pilocarpina

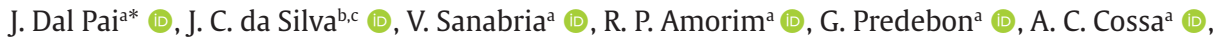 \\ E. Trindade-Filho ${ }^{\mathrm{b}, \mathrm{c}}$ (D) and D. Amado ${ }^{\mathrm{a}}$ (D) \\ aUniversidade Federal de São Paulo - UNIFESP, Neurology and Neurosurgery Department, São Paulo, SP, Brasil \\ bUniversidade Estadual de Ciências da Saúde de Alagoas - UNCISAL, Maceió, AL, Brasil \\ 'Centro Universitário CESMAC, Faculdade de Medicina, Maceió, AL, Brasil
}

\begin{abstract}
Only few studies have focus on animals that received Pilocarpine (Pilo) and did not develop behavioral status epilepticus (SE) and, whether they may become epileptic in the model's chronic phase. Previews works observed mossy fiber sprouting in the hippocampus of Non-SE (NSE) rats, while others observed spontaneous and recurrent seizures (SRS) 6 - 8 months after animals received Pilo. It is known that neuronal excitability is influenced by female hormones, as well as, the occurrence of SE in castrated and non-castrated female rats. However, it is not known whether females that received Pilo and did not show SE, may have SRS. The aim of this work was to investigate whether castrated and non-castrated female rats that did not show behavioral SE after Pilo, will develop SRS in the following one-year. For that, animals received $360 \mathrm{mg} / \mathrm{kg}$ of Pilo and were video monitored for 12 months. SE females from castrated and non-castrated groups became epileptic since the first month after drug injection. Epileptic behaviors were identified watching video monitoring recordings in the fast speed. Castrated and Noncastrated NSE animals showed behaviors resembling seizures described by Racine Scale stages 1 - 3. Motor alterations showed by NSE groups could be observed only when recordings were analyzed in slow speed. In addition, behavioral manifestations as, rhythmic head movements, sudden head movements, whole body movements and immobility were also observed in both, SE and NSE groups. We concluded that NSE female rats may have become epileptic. Adding to it, slow speed analysis of motor alterations was essential for the observation of NSE findings, which suggests that possibly many motor alterations have been underestimated in epilepsy experimental research.
\end{abstract}

Keywords: Pilocarpine, experimental model, non-Status Epilepticus, female rats, video monitoring.

\begin{abstract}
Resumo
Poucos são os estudos com foco em animais que receberam Pilocarpina (Pilo) e não desenvolveram status epilepticus (SE) comportamental e, se os mesmos se tornarão epilépticos na fase crônica do modelo. Autores observaram o brotamento das fibras musgosas no hipocampo de ratos Não-SE (NSE), enquanto outros observaram crises espontâneas e recorrentes (CER) 6 - 8 meses após receberam a droga. A excitabilidade neuronal é influenciada pelos hormônios femininos e, da mesma forma, a ocorrência de SE em ratas castradas e não-castradas. Entretanto, não é sabido se as fêmeas que não apresentam SE terão CER. O objetivo deste trabalho foi investigar se fêmeas castradas e não castradas que não tiveram SE comportamental após a injeção de Pilo desenvolverão CER dentro de um ano. Para isto, os animais receberam $360 \mathrm{mg} / \mathrm{kg}$ de Pilo e foram videomonitorados por 12 meses. As fêmeas SE castradas e não-castradas se tornaram epilépticas desde o primeiro mês pós Pilo. O comportamento epiléptico foi identificado assistindo as gravações na velocidade rápida. As fêmeas NSE castradas e não-castradas apresentaram comportamentos similares aos estágios 1 - 3 da Escala de Racine. As alterações motoras nestes grupos (NSE) foram observadas apenas quando as videomonitoração foi analisada na velocidade lenta. Além destas, manifestações comportamentais como movimentos rítmicos da cabeça, movimentos súbitos da cabeça, movimentos de todo o corpo e imobilidade também foram observadas em ambos grupos, SE e NSE. Concluímos que as fêmeas NE podem ter se tornado epilépticas. Adicionado a isto, a análise das alterações motoras na velocidade lenta foi essencial para a observação dos achados das fêmeas NSE, o que sugere que possivelmente muitas alterações motoras têm sido subestimados na pesquisa em epilepsia experimental.
\end{abstract}

Palavras-chave: Pilocarpina, modelo experimental, sem-Status Epilepticus, ratas, videomonitoramento.

*e-mail: dal.pai@unifesp.br; dalpai.janise@gmail.com

Received: May 30, 2020 - Accepted: June 4, 2021 


\section{Introduction}

Pilocarpine (Pilo) experimental model of epilepsy was first described in male rats by Turski et al. (1983), and in female rats by Amado and Cavalheiro (1998). Behavioral, pathologic and electroencephalographic characteristics found in male and female epileptic rats treated with Pilo resemble those observed in Temporal Lobe Epilepsy (TLE) patients, making this a very useful experimental model of study (Cavalheiro et al., 1994).

Over the years, many experimental research groups around the world have devoted to the study of epilepsy, but only few of them have reported the number or percentage of non-SE animals (NSE) obtained in their experiments. Previous studies from our laboratory, in which female rats were treated with Pilo, showed that $40-50 \%$ of them did not have SE (data not published). Other works obtained $29 \%$ of NSE male rats after using Pilo (Scharfman et al., 2001) and $54-88 \%$ of NSE female rats depending on estrus cycle day (Scharfman et al., 2005). Despite the common and variable occurrence of NSE rats in this model of epilepsy, the discard of this animals or the use as controls are not unusual among researchers (Mora et al., 2009). However, few studies have been done toward the comprehension of such animals.

A study found that $50 \%$ of NSE male rats induced by Pilo lost cells from the entorhinal cortex, while $17 \%$ of them showed mossy fiber sprouting. This work described that functioning abnormalities of mossy cells may arise without status epilepticus and may be related to sprouting (Scharfman et al., 2001). Other group observed SRS in NSE male rats under telemetry, 6 - 8 months after Pilo administration. Authors also reported commitment of hippocampus, piriform cortex and thalamus in MRI analysis, 1 year after Pilo injection (Mora et al., 2009).

Using the Pilo model of epilepsy, Amado and Cavalheiro (1998) observed that the estrus cycle regularity in female rats was affected by brain seizures and influenced the normal physiological functioning of hypothalamic-pituitary axis. In this sense, authors described a significant decrease in luteinizing and follicle-stimulating hormones from the pituitary, with consequent decrease in progesterone and increase in estradiol release from the ovaries. Many studies have shown that $17 \beta$-estradiol is a potent proconvulsant and plays an important role in the pathophysiology of epilepsy enhancing brain excitability (Martini et al., 1993; Woolley, 2000; Iqbal et al., 2019), thus affecting the development of seizures and rat's cyclicity. Other authors showed similar results. Valente et al. (2008) found smaller latency to the first seizure and higher number of seizures when Pilo was given to castrated female rats. This finding also contributes to the comprehension that the removal of female hormones has, as a consequence, higher neuronal brain excitability leading to seizures.

The study of the occurrence of SRS in the Pilo model's chronic phase of castrated and non-castrated SE and NSE female rats may contribute to the understanding of the influence of females' hormones in the neuronal excitability in this epilepsy model.

Considering that, the main purpose of this work was: a) to investigate the possible occurrence of SRS in castrated and non-castrated female rats that presented and did not present behavioral SE after Pilo administration; and, b) to access female's estrus cycle regularity in order to have and indirect information about the occurrence of seizures, since animals may show brain seizures without behavioral manifestations.

It is expected the occurrence of SRS in the model's chronic phase of SE and NSE castrated and non-castrated animals, with a higher number of seizures in the castratedSE group. Alteration in females' cyclicity of non-castrated-SE and -NSE females is also expected with a higher number of seizures in castrated SE animals.

\section{Materials and Methods}

\subsection{Animals}

Female Wistar adult rats, weight range $200-230 g, n=137$, with regular estrus cycle, housed under environmentally controlled conditions in a light / dark cycle (12/12h), temperature $21 \pm 2^{\circ} \mathrm{C}$ and with free access to food and water, were used. Adequate measures were taken to minimize animal's pain or discomfort. All experimental protocols were approved by the ethics committee of the UNIFESP(\#0211/12).

\subsection{Groups}

Experimental groups in this work were, NSE: female rats that did not present behavioral SE (4h of uninterrupted seizures) after Pilo administration; NSE-Cast: NSE females castrated 72h after Pilo; and, Cast-NSE: females castrated 6 days before Pilo administration and did not develop behavioral SE. As control groups, SE: females that showed behavioral SE after Pilo injection; SE-Cast: SE females castrated 72h after Pilo; Cast-SE: females castrated 6 days before Pilo administration and presented behavioral SE; and, CTL: control, females that received saline instead of Pilo (Figure 1).

\subsection{Pilocarpine administration}

Induction to experimental TLE was made in 86 regular estrous cycle female rats (in the estrus day of estrous cycle) and 48 castrated females. To prevent peripheral cholinergic pilocarpine effects, methylscopolamine ( $1 \mathrm{mg} / \mathrm{kg}$, sc, Sigma) was administered $30 \mathrm{~min}$ before Pilo (370 mg/kg, 4\%, ip., Sigma). All females (SE and NSE) received Diazepam (1 mg/kg, ip, Santisa) and Tiopental (30 mg/kg, ip., Cristália) 4 hours after Pilo administration. After that, SE and NSE rats were hydrated with saline solution $0.9 \%$ ( $3 \mathrm{ml}$ ip. and $1 \mathrm{ml} \mathrm{sc}$.) and were set alone in their cages, covered with newspaper. SE females received special cares starting on the first day after Pilo administration. These animals were hydrated and fed by mouth manually by researchers, who gave feed bran mixed with water, 4 - 5 times a day, until animals were able to feed by itself. Female rats were considered SE when uninterrupted seizures were observed for 4 hours. Racine Scale (Racine, 1972) were used for seizures identification. Animals who showed interrupted seizures, meaning that started and stopped minutes later, were considered NSE. Seventy-two hour after Pilo injection, 9 SE and 14 NSE rats were castrated. 


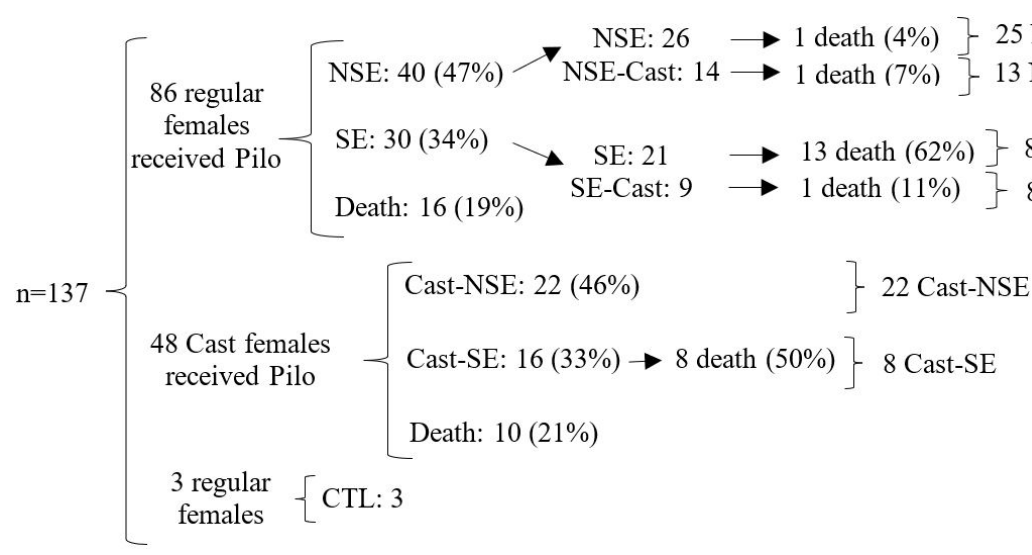

Figure 1. Experimental design and number of females obtained in each group after Pilo administration.

\subsection{Castration}

Castration was performed in female rats: a) at 6 days before Pilo injection, since findings show a significant decrease in blood sexual hormone concentration with systemic repercussions 4 days after castration (Edwards et al., 1999). Additional reports confirm the effects of castration 6 days after the procedure (McGinnis et al., 1981) or; b) at $72 \mathrm{~h}$ after Pilo injection, since studies in our laboratory show that females have a better recovery after this period. After anesthesia with ketamine $(75 \mathrm{mg} / \mathrm{kg}$, ip., Syntec) and xylazine (12 mg/kg, ip., Syntec), females had their abdomen shaved and sterilized with iodopovidone. An incision of $1.5 \mathrm{~cm}$ was made in skin and musculature in the lower midline, bilateral ovaries were identified and removed, and opened tissues were sutured. Ibuprofen ( $20 \mathrm{mg} / \mathrm{kg}$, Medley) was given by mouth once, 3 - $4 \mathrm{~h}$ after animals recovered from anesthesia, and added to bottle water ( $12 \mathrm{mg} / \mathrm{kg} /$ day per rat) for 5 days to avoid pain. No female rats were lost due to the surgery.

\subsection{Seizure classification}

Female behaviors from all groups were analyzed considering the 10 stages of seizures described by Michalakis et al. (1998): 1- facial movements only; 2- stage 1 and head nodding; 3 -stage 2 and forelimb clonus; 4- stage 3 and rearing; and 5- stage 4 and falling; stage 6, multiple stage 5 seizure; stage 7, jumping; stage 8 - running and jumping; stage 9 - stage 8 followed by tonic-clonic seizure; and, stage 10- multiple stage 9. Behaviors observed in this work that did not match those described above are presented in the results section.

\subsection{Analyzed parameters}

In all groups it was observed: the number of animals that developed or not behavioral SE after Pilo; latency to the first motor alteration and to behavioral SE; mortality; regularity of estrous cycle in non-castrated female groups (SE and NSE); frequency of spontaneous seizures in three SE groups; identification and percentage of seizures-like behaviors in three NSE groups; and, identification and description of other behavior patterns for all experimental groups.

\subsection{Estrous cycle access}

In order to access estrous cycle regularity, vaginal smearing was collected 2 - 3 weeks/month during one-year follow-up experiment from 6SE, 18 NSE and 3 control female rats. Smears were taken between 8:00 - 9:00 a.m. using a plastic pipette tip filled with 10 ul of saline solution, by inserting the tip (not deeply) into the rat vagina. The unstained material collected was transferred to a glass slide and observed under a light microscope. The presence of specific types of cells indicated the phase of estrous cycle, as follow: proestrus phase, large amount of round and nucleated cells; estrus phase: anucleated cornified epithelial cells; metestrus phase, round nucleated epithelial cells with leukocytes; and, diestrus phase: large amount of leukocytes. The regular estrous cycle is defined by the presence of estrous phase every 3 to 4 days (Marcondes et al., 2002; Cora et al., 2015). All external stimuli that could possibly alter rats' cyclicity were avoided.

\subsection{Video monitoring}

After recovering from Pilo injection, females were taken to video monitoring room, which is equipped with IR-light video cameras coupled to a recording system, VD16E480C model, Intelbrás (Brazil). Each group was video recorded 14 days / month starting 2 - 3 weeks after Pilo or saline injection and followed for one year. Due to the complexity in obtaining SE-Cast females, this group were video recorded from $1^{\text {st }}-4^{\text {th }}$ map (month after Pilo) only. For a better identification of animal motor alterations, recordings were analyzed in periods as follow: $1^{\text {st }}-4^{\text {th }}, 5^{\text {th }}$ $-8^{\text {th }}$ and $9^{\text {th }}-12^{\text {th }}$ map. CTL group was not video recorded. Video recordings obtained were analyzed in fast speed (the maximum system speed) by two researchers blinded for the experimental condition.

Twelve hours recordings from 7 NSE, 4 Cast-NSE and 6 NSE-Cast females randomly chosen were watched again in slow speed (the same speed in which movements occur), after fast speed analysis. Since electroencephalography (EEG) could not be performed in this work, manifestations that resemble seizures in these groups were considered seizure-like behavior. 


\subsection{Statistical analysis}

Results are shown in terms of mean $\pm \mathrm{SD}$, mean $\pm \mathrm{SE}$ and the $95 \%$ of confidence interval (CI). Differences were considered significant when $\mathrm{p} \leq 0.05$ for all analyzes. Results obtained and without normality, nor homogeneity, were transformed into Z-Score. Two way ANOVA and Tukey's post hoc tests were applied to test: the difference in the number of SE females obtained from regular estrous cycle and Cast females; latency to SE; number of seizures among SE groups over observation periods; number of seizures accompanied by behavioral manifestations in SE female groups; number of seizures (alone) and number of behavioral manifestations (alone) in SE female groups; number of seizure-like behaviors among NSE groups over observation periods; number of seizure-like behaviors accompanied of behavioral manifestations in NSE female groups; and, number of seizure-like behaviors (alone) and behavioral manifestations (alone) in NSE female groups. Mann-Whitney test was used for the latency to first motor alteration, T-Test was applied for mortality caused by tonic seizure and in the course of SE. Statistical procedures were performed using GraphPad Software Prism 4.0.

\section{Results}

\subsection{Groups}

Forty NSE and 30 SE rats out of 86 regular estrous cycle females were obtained after Pilo administration in the estrus day of the cycle (16 died due to tonic seizure) (Figure 1). Fourteen out of 40 NSE females were castrated $72 \mathrm{~h}$ after Pilo injection, giving rise to NSE-Cast group. One NSE and 1 NSE-Cast rat died, resting respectively 25 and 13 females in each group (Figure 1). Nine out of 30 SE females were castrated $72 \mathrm{~h}$ after Pilo, originating SE-Cast group (1 died). From the 21 SE rats obtained, 13 died $24-72 \mathrm{~h}$ after Pilo administration. Thus, 8 females remained in the SE group and in SE-Cast, as well. From the 48 females castrated 6 days before Pilo administration, 22 did not show behavioral SE, while 16 did. Ten castrated females died after drug injection due to tonic seizure and 8 out of 16 Cast-SE died 24 - 72h after Pilo. Thus, Cast-NSE and Cast-SE group had respectively 22 and 8 females each. Three regular estrous cycle female rats constituted the control group during 1-year experiment.

Concerning the number of animals that showed behavioral SE after Pilo injection, statistics significance was found when regular estrous cycle females and Cast animals were compared. Data obtained was regular estrous cycle $(8.75 \pm 1.77)$ (mean \pm SD) and Cast females (4.75 \pm 1.06), $\mathrm{F}(1,12)=12.39, \mathrm{p}<0.01$.

\subsection{Latencies after Pilo injection}

Females that developed behavioral SE after Pilo showed quietness followed by masticatory automatisms, salivation, head nodding and body shakes. Limbic behaviors repeated every 3 - 8 min until behavioral SE was observed. Latency to first motor alteration was higher is castrated females $12.71-19.96 \min (16.33 \pm 2.27$ min mean $\pm \mathrm{SE})$ than in non-castrated females (regular estrous cycle animals) 4.38 - $14.52 \mathrm{~min}(9.45 \pm 2.27$ min mean $\pm \mathrm{SE})$, confidence interval (CI) (95\%) was considered, $\mathrm{p}<0.05$ (Figure 2A). Castrated females also showed more aggressive behaviors as tonic and tonic-clonic seizures than non-castrated animals. Latency to SE (T- Student Test) were smaller in non-castrated (CI: $20.41-26.44 \mathrm{~min} ; 23.43 \pm 1.23 \mathrm{~min}$ mean \pm SD) than in castrated rats (CI: 24.48 - $31.52 \mathrm{~min}$; $28 \pm 1.48$ min mean \pm SD), $\mathrm{p}<0.05, \mathrm{CI}(95 \%)$ was considered for both groups (Figure 2B). Values of mortality between groups were not significant. Animals where behavioral SE was not observed, showed inconsistent seizures up to stage 3 of Racine Scale (Racine, 1972), with marked beginning and end.
A.

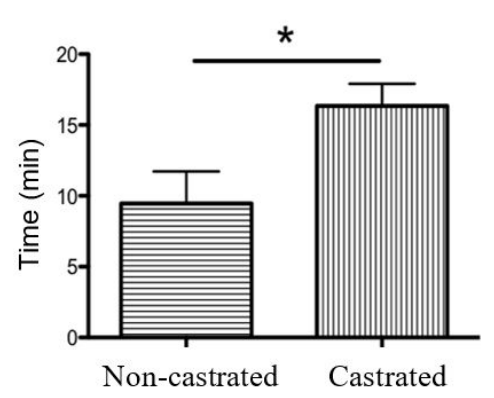

Non-castrated: $\mathrm{X} \pm \mathrm{ED}(9,45 \pm 2,27 \mathrm{~min}), \mathrm{IC}$ (95\%): 4,38 - 14,52 min., n: 86.

Castrated: $\mathrm{X} \pm \operatorname{ED}(16,33 \pm 2,27 \mathrm{~min}), \mathrm{IC}(95 \%)$ :

12,71 - 19,96 min., n: 48

Mann-Whitney $\mathrm{U}: 21$

${ }^{*} \mathrm{p}=0,0328$.

Bars represent average and error deviation IC: confidence interval; X: average; ED: error deviation
B.

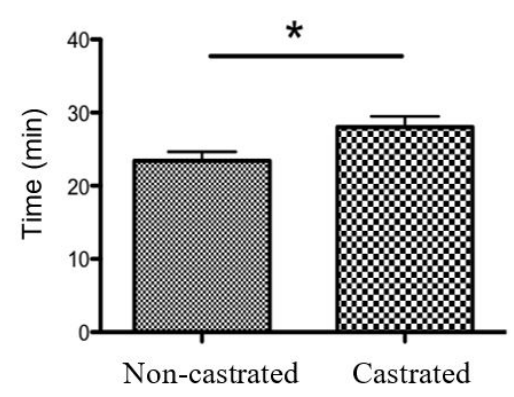

Figure 2. Latency in non-castrated and castrated groups. A. Latency to first motor alteration. B. Latency to SE. 


\subsection{Estrous cycle}

Five out of 6 (83\%) SE females showed irregularity from $1^{\text {st }}-4^{\text {th }}$ map, while all of them became irregular from $5^{\text {th }}$ $12^{\text {th }}$ months of experiment. In NSE females, irregularity was observed in 6 of 18 (33\%) rats up to 3 map, 16 of 18 (89\%) from $5^{\text {th }}-8^{\text {th }}$ map and 9 of 14 females $(64 \%)$ from $9^{\text {th }}-12^{\text {th }}$ months of experiment. Irregularity was observed in terms of constant estrus at vaginal smearing. CTL female group showed only few periods of irregularity during the experiment.

\subsection{Findings from SE, Cast-SE and SE-Cast groups}

All females from SE, Cast-SE and SE-Cast groups became epileptic since the $1^{\text {st }}$ map. Video recordings of these groups were watched in fast speed, which showed that seizures persisted for the 12 months observation period. These animals showed seizures stage 8 , as described by Michalakis et al. (1998), however more than 50\% of all seizures were among stage 5-7.

Seizures of all SE groups were observable using fast speed analysis approach. After seizures identification, a second analysis was done in slow speed for details description. This double checking showed that seizures were accompanied of a variety of different manifestations as, isolated head movements, whole body movements and, immobility. These behavioral manifestations were classified as follow: 1) Head Rhythmic (HR) manifestations: identified as oscillatory head movements that included, side-to-side, up-and-down and back-and-forth; 2) Head Sudden (HS) manifestations: movements usually with high amplitude as, head projection and/or retraction, drop, version (sometimes accompanied of neck and/or trunk (hyper)extension); 3) Whole Body (WB) manifestations: involved head, trunk and limbs as follow, shaking, fast walking in circles, 90 - $360^{\circ}$ spin and imbalance; and, 4) Immobility (IM) manifestation: the absence of movements with eyes open (staring eyes).

Authors observed the presence of seizures and behavioral manifestations in all SE groups along the oneyear observation period (Table 1). Sixty-nine percent of SE female seizures were accompanied of WB manifestations, between the $5^{\text {th }}-8^{\text {th }}$ map, while $100 \%$ of them showed HS or IM from the $9^{\text {th }}-12^{\text {th }}$ map. SE-Cast group also showed frequent seizures accompanied of WB, and / or IM manifestations. On the other hand, SE females, between the $1^{\text {st }}-4^{\text {th }}$ map, and, Cast-SE group, from $1^{\text {st }}-4^{\text {th }}$ map and $5^{\text {th }}-8^{\text {th }}$ map, showed seizures not frequently accompanied by behavioral manifestations. The Cast-SE group showed only seizures (without behavioral manifestations) from the $9^{\text {th }}-12^{\text {th }}$ map, as indicated in Table 1 .

Among SE females, the occurrence of IM was commonly seen during seizures stage 3 - 5, and lasts from 10 seconds to 5 minutes. Behavioral manifestations also occurred alonewithout seizures, in less than $10 \%$ of SE, Cast-SE and SE-Cast groups. HS and WB manifestation were the most identified as, sudden neck extension followed by imbalance or head version; and, shaking and spin, respectively. The videos of manifestations described in this work are available in the supplemental material.

Initially, all animals obtained in SE groups were settled at the video monitoring room, however few of them had to be removed to give place to other ongoing researches. Researchers of this work also had hard time getting SE group. Figure 1 shows the number of animals that died due to tonic seizures right after Pilo administration $(n=16$, 19\%) and 24 - 72 hours after drug injection ( $n=13,62 \%)$. Since females of SE-Cast group depend on SE female's survival, it took a long time to get SE-Cast females (even with $72 \mathrm{~h}$ recovering period to SE females between Pilo injection and castration procedure). As a consequence, video recordings of SE-Cast females could be watched only until the $4^{\text {th }}$ map administration.

Statistics did not show difference in the number of seizures among SE groups over observation periods. No significance was observed when the number of seizures and seizures accompanied of behavioral manifestations were compared among SE groups. The same was observed for SE, Cast-SE and SE-Cast females when the number of seizures (alone) and behavioral manifestations (alone) were compared.

\subsection{Findings from NSE, Cast-NSE and NSE-Cast}

Different from SE groups, whose seizures were observed in fast speed analysis, video recording analysis of NSE, Cast-NSE and NSE-Cast, done initially in fast speed, did not evidence any motor alteration. This negative result raised the question

Table 1. Number and percentage of seizures and behavioral manifestations along one-year follow-up experiment in SE, Cast-SE and SE-Cast groups.

\begin{tabular}{ccccc}
\hline Groups & $\begin{array}{c}\text { Period (map) } \\
\text { and } \mathbf{n} \text { of rats }\end{array}$ & $\begin{array}{c}\text { Number of } \\
\text { seizures }\end{array}$ & $\begin{array}{c}\text { Number and \% of seizures } \\
\text { with manifestations }\end{array}$ & Behavioral Manifestation \\
\hline SE (n=8) & $1^{\text {st }-4^{\text {th }}(\mathrm{n}=8)}$ & 132 & $5(4 \%)$ & WB: spin \\
& $5^{\text {th }}-8^{\text {th }}(\mathrm{n}=4)$ & 148 & $102(69 \%)$ & HS: neck extension; and/or, IM \\
& $9^{\text {th }}-12^{\text {th }}(\mathrm{n}=1)$ & 4 & $4(100 \%)$ & HS: neck and trunk hyperextension; WB: \\
shaking and/or, IM
\end{tabular}

$\mathrm{SE}=$ epileptic; Cast-SE = castrated and then epileptic; SE-Cast = epileptic and then castrated; $\mathrm{n}=$ number; map = months after pilo; $\%=$ percentage; $\mathrm{HR}=$ head rhythmic manifestation; $\mathrm{HS}=$ head sudden manifestation; WB = whole body manifestation; $\mathrm{IM}=$ immobility. Kruskal-Wallis $\mathrm{KW}=3$, $\mathrm{p}>0.05$. 
whether the fast speed analysis could hinder the observation of female's manifestations, which were possibly hidden by fast analysis approach. To answer this, 12 hour of recordings (3 hours per night) of 4 following nights, were reassessed. Dark period was chosen because animals are more active on this period (Zhang et al., 2000). For that, 7 NSE, 4 CastNSE and 6 NSE-Cast females, from all observation periods, were re-analyzed in slow speed. Since this approach is very time consuming, these animals could not be followed along the one-year experiment. Due to technical issues, Cast-NSE females were reassessed from $1^{\text {st }}$ to $8^{\text {th }}$ map.

Reassessment of video recordings in slow speed confirmed the presence of behaviors that resemble seizures stage 1 - 3 of Racine (1972). Seizure-like behaviors were observed alone and also accompanied of behavioral manifestations, but no statistically difference were found among NSE groups. All seizure-like behaviors identified in NSE and NSE-Cast females between $1^{\text {st }}-4^{\text {th }}$ map were followed at least for one of the behavioral manifestations described in this work. The most commonly observed were, HS and WB manifestations and, HS manifestation, respectively. Seizure-like behaviors observed in NSE-Cast group from $5^{\text {th }}-8^{\text {th }}$ map and $9^{\text {th }}-12^{\text {th }}$ map, were all accompanied by HR manifestations. Different from that, were for NSE females between $5^{\text {th }}-8^{\text {th }}$ map and $9^{\text {th }}-12^{\text {th }}$ map, which had up to $25 \%$ of all seizure-like behaviors accompanied of behavioral manifestations. These females showed HS and WB manifestations in the intermediate observation period and the same WB manifestation (walking in circles) in the last period (Table 2 ).

In the initial period observation ( $1^{\text {st }}-4^{\text {th }}$ map) for the Cast-NSE group, all seizure-like behaviors were followed by HS and IM manifestations. For the next period, HS manifestation was present in $60 \%$ of all seizure-like behaviors. The period from $9^{\text {th }}-12^{\text {th }}$ map, was not reassessed in slow speed (Table 2). HS manifestations as, head projection and retraction, head version and shaking were also observed alone- not accompanied of seizurelike behaviors. Videos are available in the supplemental material.

In addition, other manifestations were also observed, although less frequent, in the NSE, Cast-NSE and NSE-Cast groups, which included: sudden abdominal contraction (similar to a hiccup), posterior paws clonus, circling movements, imbalance and tail rigidity. Table 2 refers to NSE groups that had 12 hours of their video recordings reassessed in slow speed, since fast speed observation did not evidence any motor alteration.

Statistical evaluation among NSE groups regarding the number of seizure-like behaviors occurred over the course of a year. Significance were observed in the periods: $1-4$ map $(1.33 \pm 0.92)($ mean $\pm S D)$ and $5-8$ map $(0.76 \pm 0.71)$ and $5-8$ and $9-12$ map $(0.43 \pm 0.28)$, $\mathrm{F}(2.4)=21.43, \mathrm{p}<0.01$ (Figure $3 \mathrm{~A}$ ). Comparing the number of seizure-like behaviors and seizure-like behaviors accompanied of behavioral manifestations in NSE, Cast-NSE and NSE-Cast females, did not show significance. However, statistical difference was observed when the number of seizure-like behaviors and behavioral manifestations were compared in the periods of: $1-4$ map $(1.33 \pm 1.01)$ (mean \pm SD) and $5-8$ map (1.42 \pm 2.23$) ; 1-4$ map $(1.33 \pm 1.01)$ and $9-12$ map $(0.85 \pm 0.89)$; and, between $5-8$ map $(1.42 \pm 2.23)$ and $9-12$ map $(0.85 \pm 0.89)$, $\mathrm{F}(2.4)=133.8, \mathrm{p}<0.001$ (Figure 3B).

\section{Discussion}

This work was based on a one-year video monitoring follow-up of castrated and non-castrated SE and NSE female rats that showed 4 classes of behavioral manifestations in the Pilo model's chronic phase.

Castrated and non-castrated female rats showed manifestations similar to that described by others after receiving Pilo (Valente et al., 2002; Campos et al., 2017).

Table 2. Number and percentage of seizure-like behavior and behavioral manifestations in NSE, Cast-NSE and NSE-Cast females (based on $12 \mathrm{~h}$-slow speed observation).

\begin{tabular}{|c|c|c|c|c|}
\hline Groups & Period (map) & $\begin{array}{c}\text { Number of } \\
\text { seizure-like/stage }\end{array}$ & $\begin{array}{l}\text { Number and \% of seizure- } \\
\text { like with manifestations }\end{array}$ & Behavioral Manifestation \\
\hline \multirow[t]{3}{*}{$\begin{array}{l}\text { NSE } \\
(\mathbf{n}=7)\end{array}$} & $1^{\text {st }}-4^{\text {th }}(n=3)$ & $8 / 2-3$ & $8(100 \%)$ & $\begin{array}{c}\text { HS: head version, neck extension; and/or, } \\
\text { WB: shaking }\end{array}$ \\
\hline & $5^{\text {th }}-8^{\text {th }}(n=2)$ & $4 / 1$ & $1(25 \%)$ & $\begin{array}{l}\text { HS: neck extension followed by head } \\
\text { version; and/or, WB: walking in circles }\end{array}$ \\
\hline & $9^{\text {th }}-12^{\text {th }}(\mathrm{n}=2)$ & $6 / 2-3$ & $1(17 \%)$ & WB: walking in circles and shaking \\
\hline \multirow[t]{2}{*}{$\begin{array}{c}\text { Cast-NSE } \\
\quad(n=4)\end{array}$} & $1^{\text {st }}-4^{\text {th }}(n=2)$ & $8 / 2-3$ & $8(100 \%)$ & $\begin{array}{l}\text { HS: head and trunk version and/or, neck } \\
\text { extension and hyperextension; and/or, IM }\end{array}$ \\
\hline & $5^{\text {th }}-8^{\text {th }}(n=2)$ & $5 / 2-3$ & $3(60 \%)$ & $\begin{array}{l}\text { HS: head projection and retraction, and/ } \\
\text { or, neck and trunk (hyper)extension }\end{array}$ \\
\hline \multirow[t]{3}{*}{$\begin{array}{l}\text { NSE-Cast } \\
(\mathrm{n}=6)\end{array}$} & $1^{\text {st }}-4^{\text {th }}(n=2)$ & $3 / 2-3$ & $3(100 \%)$ & $\begin{array}{l}\text { HR: head version, neck extension; and/or, } \\
\text { WB: shaking }\end{array}$ \\
\hline & $5^{\text {th }}-8^{\text {th }}(n=2)$ & $3 / 2-3$ & $3(100 \%)$ & $\begin{array}{l}\text { HR: side-to-side oscillation; HS: head } \\
\text { version and/or, head and trunk extension }\end{array}$ \\
\hline & $9^{\text {th }}-12^{\text {th }}(\mathrm{n}=2)$ & $3 / 3$ & $2(100 \%)$ & $\begin{array}{l}\text { HR: side-to-side oscillation; HS: head } \\
\text { version and/or, head and trunk extension }\end{array}$ \\
\hline
\end{tabular}

NSE = non- epileptic; Cast-NSE = castrated and non-epileptic; NSE-Cast = non-epileptic and then castrated; $\mathrm{n}=$ number; map = months after pilo; $\mathrm{HR}=$ head rhythmic manifestation; $\mathrm{HS}=$ head sudden manifestation; WB = whole body manifestation; IM = immobility. Kruskal-Wallis $\mathrm{KW}=4.84, \mathrm{p}>0.05$. 
A.

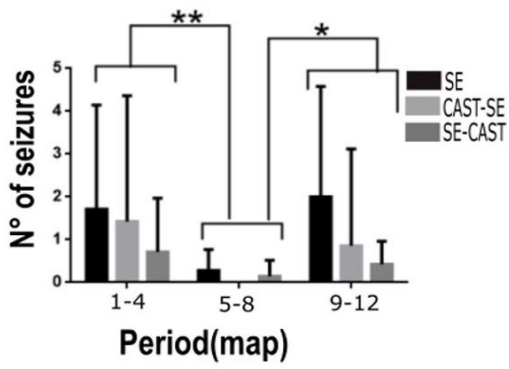

B.

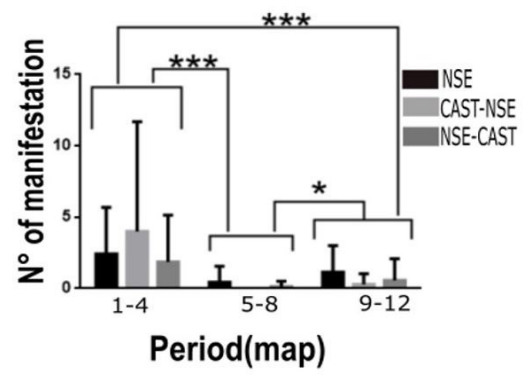

Figure 3. A. Number of seizures in SE, Cast-SE and SE-Cast. B. Number of manifestations in NSE, Cast-NSE and NSE-Cast groups. KruskalWallis test KW = 7.38, followed by Post-hoc Dunn was done. SE: epileptic $(n=8)$; Cast-SE: castrated and then epileptic ( $\mathrm{n}=4$ ); SE-Cast: epileptic and then castrated $(\mathrm{n}=3)^{*} \mathrm{p}<0.05,{ }^{* *} \mathrm{p}<0.01,{ }^{* * *} \mathrm{p}<0.001$.

Non-castrated females also presented tail rigidity, head and/or body shaking and sudden neck extension. Castrated females showed rearing, tonic and tonic-clonic seizures. The absence of neuronal protection offered by female hormones stated by Valente et al. (2002), was probably the reason why castrated females showed severe responses than non-castrated. Different from these authors, we found that castrated females had higher latency to the first motor alteration and to SE after Pilo administration, than non-castrated animals, which is not expected. This probably happened because Ibuprofen, a pain relief drug with anti-inflammatory action, was given to females right after recovering from castration and, for the following 5 days. Corroborating to that, Wallenstein $(1987,1991)$ found higher latency to seizure beginning when Ibuprofen was given to female rats $1 \mathrm{~h}$ before being submitted to Penicillin and PTZ model. In another sense, Ibuprofen administration contributed to females' recovery, since only 1 out of 9 SE-Cast animals died after gonadal removal.

Long term estrus cycle follow-up showed that irregularity was present in SE females since the first months after Pilo injection and also in all females from $5^{\text {th }}-12^{\text {th }}$ map. Our findings are in agreement with the literature of Amado and Cavalheiro (1998) and Campos et al. (2017), meaning that these animals were affected by Pilo. As expected, estrus cycle irregularity could be correlated with seizure evidenced in these animals along the one-year follow up. Exception was made for one out of 6 animals that did not show irregularity until the $4^{\text {th }}$ map. As expected, NSE females also presented estrous cycle irregularity along the observation period, showing that they were probably affected by Pilo injection. The motor alterations observed in these females also suggest that they were affected by Pilo, although a correlation is not possible, since our results are based on the reassessment of $12 \mathrm{~h}$ video recordings observation.

In our work, SRS of SE female groups were observed through video monitoring analysis in fast speed which showed a higher number of seizures in SE females $(n=8)$ comparing to SE-Cast $(n=3)$ between the period of $1^{\text {st }}-4^{\text {th }}$ map. This probably occurred due to the amount of animals analyzed in each group in this period. Manifestations observed in SE groups were described in the kindling model of epilepsy (Michalakis et al., 1998).
Considering NSE groups, no seizures were observed when video monitoring analysis was done in fast speed. However, motor alterations that resemble seizures stages 1 - 3 (Racine, 1972), as well as, the four classes of behavioral manifestations, in both, SE and NSE groups, became observable when recordings were re-analyzed in the slow speed mode.

Other manifestations, described in animal models and also in patients, were frequently observed in this work in SE and NSE groups, when slow speed analysis were applied. Up and down head oscillation, an HR manifestation, were observed in SE animals, and resemble head drops movements seen in epileptic patients, which are cortical myoclonus involving neck muscles in the spectrum of myoclonicastatic epilepsy (Antelmi et al., 2016). This alteration was also described in patients with chorea-acanthocytosis, accompanied of neck extension spasms (Schneider et al., 2010), which are similar to findings of SE and NSE females that showed neck extension, sometimes followed by neck hyperextension and also head version (HS manifestations). Spin movements, an WB manifestation, were identified in this work in SE groups. This manifestation is very similar to the definition of gyratory seizures, which are described as a rotation around the body axis, of at least 180 degrees, during a seizure, observed in $2 \%$ of TLE patients, and also in animals (Vercueil et al., 1999; Dobesberger et al., 2005). As stated by Dobesberger et al. (2005), gyratory seizures start with head version followed by body version in $58 \%$ of the $2 \%$ of TLE patients. These both HS manifestations were observed alone or together, in SE and NSE groups as well. Shaking, was another HS manifestation commonly observed in SE and NSE females, which are similar to wet dog shakes observed in other animal models of seizures as, kainic acid, organophosphate pesticide and quinolinic acid (Nirwan et al., 2018). Immobility, previously described in the hyperthermia model of febrile seizures in pups, was observed in SE and also NSE females in this work (Nirwan et al., 2018).

Concerning the limitations of this study, EEG application would have confirmed manifestations observed in NSE groups and probably helped in identifying structures involved, but this methodology could not be elected in this work. The estrous cycle and motor findings of NSE rats could not be correlated since data of this group is based on the 
reassessment of $12 \mathrm{~h}$ video recordings. Despite limitations, important motor findings especially concerning the four classes of behavioral manifestations in NSE, Cast-NSE and NSE-Cast females could be identified, which suggests that these females were affected by Pilo administration and possibly have developed an epileptic focus.

Further studies comprising the identification of seizurelike behaviors and manifestations observed in this work, associated to electrophysiological methods, will help identifying structures and pathways involved in the Pilo model, and in directing drug treatments, as well.

\section{Conclusion}

This work brings important and new evidences to the experimental epilepsy field: 1) behavior manifestations identified in NSE, Cast-NSE and NSE-Cast females, already described in the literature in patients with epilepsy and animal models, suggesting that these animals probably presented partial seizures after Pilo administration; and, 2) slow speed analysis of video monitoring recordings is essential for the identification of behavioral manifestations, which possibly have been underestimated in experimental epilepsy research.

\section{Acknowledgements}

Funding Brazilian agencies for supporting this research, Coordenação de Aperfeiçoamento de Pessoal de Nível Superior (CAPES), Conselho Nacional de Pesquisa (CNPq) e Fundação de Amparo à Pesquisa do Estado de São Paulo (FAPESP).

\section{References}

AMADO, D. and CAVALHEIRO, E.A., 1998. Hormonal and gestational parameters in female rats submitted to the pilocarpine model of epilepsy. Epilepsy Research, vol. 32, no. 1-2, pp. 266-274. http:// dx.doi.org/10.1016/S0920-1211(98)00057-6. PMid:9761326.

ANTELMI, E., PLAZZI, G., ERRO, R., TINUPER, P., BALINT, B., LIGUORI, R. and BHATIA, K.P., 2016. Intermittent head drops: the differential spectrum. Journal of Neurology, Neurosurgery, and Psychiatry, vol. 87, no. 4, pp. 414-419. http://dx.doi.org/10.1136/jnnp-2015310864. PMid:26085650.

CAMPOS, D.V., LOPIM, G.M., SILVA, D.A., ALMEIDA, A.A., AMADO, D. and ARIDA, R.M., 2017. Epilepsy and exercise: an experimental study in female rats. Physiology $\mathcal{E}$ Behavior, vol. 171, pp. 120-126. http://dx.doi.org/10.1016/j. physbeh.2016.12.040. PMid:28069460.

CAVALHEIRO, E.A., FERNANDES, M.J., TURSKI, L. and NAFFAHMAZZACORATTI, M.G., 1994. Spontaneous recurrent seizures in rats: amino acid and monoamine determination in the hippocampus. Epilepsia, vol. 35, no. 1, pp. 1-11. http://dx.doi. org/10.1111/j.1528-1157.1994.tb02905.x. PMid:8112229.

CORA, M.C., KOOISTRA, L. and TRAVLOS, G., 2015. Vaginal cytology of the laboratory rat and mouse: review and criteria for the staging of the estrous cycle using stained vaginal smears. Toxicologic Pathology, vol. 43, no. 6, pp. 776-793. http://dx.doi. org/10.1177/0192623315570339. PMid:25739587.

DOBESBERGER, J., WALSER, G., EMBACHER, N., UNTERBERGER, I., LUEF, G., BAUER, G., BENKE, T., BARTHA, L., ORTLER, M. and
TRINKA, E., 2005. Gyratory seizures revisited: a video-EEG study. Neurology, vol. 64, no. 11, pp. 1884-1887. http://dx.doi. org/10.1212/01.WNL.0000163774.24004.8F. PMid:15955938.

EDWARDS, H.E., BURNHAM, W.M., MENDONCA, A., BOWLBY, D.A. and MACLUSKY, N.J., 1999. Steroid hormones affect limbic afterdischarge thresholds and kindling rates in adult female rats. Brain Research, vol. 838, no. 1-2, pp. 136-150. http:// dx.doi.org/10.1016/S0006-8993(99)01619-4. PMid:10446326.

IQBAL, R., AHMED, S., JAIN, G.K. and VOHORA, D., 2019. Design and development of letrozole nanoemulsion: a comparative evaluation of brain targeted nanoemulsion with free letrozole against status epilepticus and neurodegeneration in mice. International Journal of Pharmaceutics, vol. 565, pp. 20-32. http://dx.doi.org/10.1016/j.jpharm.2019.04.076. PMid:31051232.

MARCONDES, F.K., BIANCHI, F.J. and TANNO, A.P., 2002. Determination of the estrous cycle phases of rats: some helpful considerations. Brazilian Journal of Biology = Revista Brasileira de Biologia, vol. 62, no. 4a, pp. 609-614. http://dx.doi.org/10.1590/S151969842002000400008. PMid:12659010.

MARTINI, L., MELCANGI, R.C. and MAGGI, R., 1993. Androgen and progesterone metabolism in the central and peripheral nervous system. The Journal of Steroid Biochemistry and Molecular Biology, vol. 47, no. 1-6, pp. 195-205. http://dx.doi.org/10.1016/09600760(93)90075-8. PMid:8274436.

MCGINNIS, M.Y., KREY, C.K., MACLUSKY, N.J. and MCEWEN, B.S., 1981. Steroid receptor levels in intact and ovariectomized estrogen-treated rats: an examination of quantitative, temporal and endocrine related factors influencing the efficacy of an estradiol stimulus. Neuroendocrinology, vol. 33, no. 3, pp. 158-165. http://dx.doi.org/10.1159/000123222. PMid:6117024.

MICHALAKIS, M., HOLSINGER, D., IKEDA-DOUGLAS, C., CAMMISULI, S., FERBINTEANU, J., DESOUZA, C., DESOUZA, S., FECTEAU, J., RACINE, R.J. and MILGRAM, N.W., 1998. Development of spontaneous seizures over extended electrical kindling I. Electrographic, behavioral, and transfer kindling correlates. Brain Research, vol. 793, no. 1-2, pp. 197-211. http://dx.doi. org/10.1016/S0006-8993(98)00155-3. PMid:9630628.

MORA, G.N., BRAMANTI, P., OSCULATI, F., CHAKIR, A., NICOLATO, E., MARZOLA, P., SBARBATI, A. and FABENE, P.F., 2009. Does Pilocarpine-induced epilepsy in adult rats require status epilepticus? PLoS One, vol. 4, no. 6, pp. e5759. http://dx.doi. org/10.1371/journal.pone.0005759. PMid:19503612.

NIRWAN, N., VYAS, P. and VOHORA, D., 2018. Animal models of status epilepticus and temporal lobe epilepsy: a narrative review. Reviews in the Neurosciences, vol. 29, no. 7, pp. 757-770. http://dx.doi.org/10.1515/revneuro-2017-0086. PMid:29565791.

RACINE, R.J., 1972. Modification of seizure activity by electrical stimulation. I. After-discharge threshold. Electroencephalography and Clinical Neurophysiology, vol. 32, no. 3, pp. 269-279. http:// dx.doi.org/10.1016/0013-4694(72)90176-9. PMid:4110396.

SCHARFMAN, H.E., GOODMAN, J.H., RIGOULOT, M., BERGER, R.E., WALLING, S.G., MERCURIO, T.C., STORMES, K.S. and MACLUSKY, N.J., 2005. Seizure susceptibility in intact and ovariectomized female rats treated with the convulsant pilocarpine. Experimental Neurology, vol. 196, no. 1, pp. 73-86. http://dx.doi.org/10.1016/j. expneurol.2005.07.007. PMid:16084511.

SCHARFMAN, H.E., SMITH, K.L., GOODMAN, J.H. and SOLLAS, A.L., 2001. Survival of dentate hilar mossy cells after pilocarpineinduced seizures and their synchronized burst discharges with area CA3 pyramidal cells. Neuroscience, vol. 104, no. 3, pp. 741-759. http://dx.doi.org/10.1016/S0306-4522(01)00132-4. PMid: 11440806. 
SCHNEIDER, S.A., LANG, A.L., MORO, E., BADER, B., DANEK, A. and BHATIA, K.P., 2010. Characteristic head drops and axial extension in advanced chorea-acanthocytosis. Movement Disorders, vol. 25, no. 10, pp. 1487-1491. http://dx.doi.org/10.1002/mds.23052. PMid:20544815.

TURSKI, W.A., CAVALHEIRO, E.A., SCHWARZ, M., CZUCZWAR, S., KLEINROK, Z. and TURSKI, L., 1983. Limbic seizures produced by pilocarpine in rats: behavioural, electroencephalographic and neuropathological study. Behavioural Brain Research, vol. 9, no. 3, pp. 315-335. http://dx.doi.org/10.1016/0166-4328(83)901365. PMid:6639740.

VALENTE, S.G., MARQUES, R.H., BARACAT, E.C., CAVALHEIRO, E.A., NAFFAH-MAZZACORATTI, M.G. and AMADO, D., 2008. Effect of hormonal replacement therapy in the hippocampus of ovariectomized epileptic female rats using the pilocarpine experimental model. Epilepsy Research, vol. 82, no. 1, pp. 46-56. http://dx.doi.org/10.1016/j.eplepsyres.2008.07.003. PMid: 18760902

VALENTE, S.G., NAFFAH-MAZZACORATTI, M.G., PEREIRA JUNIOR, M., SILVA, I., SANTOS, N.F., BARACAT, E.C., CAVALHEIRO, E.A. and AMADO, D., 2002. Castration in female rats modifies the development of the pilocarpine model of epilepsy. Epilepsy Research, vol. 49, no. 3, pp. 181-188. http://dx.doi.org/10.1016/ S0920-1211(02)00024-4. PMid:12076839.
VERCUEIL, L., KAHANE, P., FRANÇOIS-JOUBERT, A., HIRSCH, E., HOFFMANN, D., DEPAULIS, A. and MARESCAUX, C., 1999. Basal ganglia involvement in rotational seizures. Epileptic Disorders, vol. 1, no. 2, pp. 107-112. PMid:10937140.

WALLENSTEIN, M.C., 1987. Attenuation of penicillin models of epilepsy by nonsteroidal anti-inflammatory drugs. Experimental Neurology, vol. 98, no. 1, pp. 152-160. http:// dx.doi.org/10.1016/0014-4886(87)90080-X. PMid:3115810.

WALLENSTEIN, M.C., 1991. Attenuation of epileptogenesis by nonsteroidal anti-inflammatory drugs in the rat. Neuropharmacology, vol. 30, no. 6, pp. 657-663. http://dx.doi. org/10.1016/0028-3908(91)90087-R. PMid:1922684.

WOOLLEY, C.S., 2000. Estradiol facilitates kainic acid-induced, but not flurothyl-induced, behavioral seizure activity in adult female rats. Epilepsia, vol. 41, no. 5, pp. 510-515. http://dx.doi. org/10.1111/j.1528-1157.2000.tb00203.x. PMid:10802755.

ZHANG, B.L., ZANNOU, E. and SANNAJUST, F., 2000. Effects of photoperiod reduction on rat circadian rhythms of $B P$, heart rate, and locomotor activity. American Journal of Physiology. Regulatory, Integrative and Comparative Physiology, vol. 279, no. 1, pp. R169-R178. http://dx.doi.org/10.1152/ajpregu.2000.279.1.R169. PMid:10896879. 


\section{Supplementary Material}

Supplementary material accompanies this paper.

Video \#1- SE 1-18: exploring and smelling, head and trunk retraction, tail rigidity with anterior paws clonus, right posterior paw clonus, right posterior paw clonus and rearing.

Video \#2- SE-Cast 4-36_2: head and trunk retraction followed by posterior paw clonus.

Video \#3- SE-Cast 4-37_2: under two posterior paws, up and down head and trunk oscillation movements, head and trunk retraction, animal under two posterior paws and sudden fall under 4 paws.

Video \#4- Cast-SE 5-8_2: aleatory exploring, up and down head and trunk oscillation movements, mastication, small head retraction, animal under two posterior paws, rearing, falling, facial movements with anterior paws clonus, rearing, posterior paws clonus with a small jump, successive anterior and posterior paws clonus with rearing and falling, immobility (10 seconds) and successive strong jumps.

Video \#5- NSE 2-5: anterior paws clonus and masticatory movements.

Video \#6- NSE 3-10_2: masticatory movements.

Video \#7- NSE 1-13_3: movement resembling a strong hiccup with anterior body advance, followed by a 90o spin with neck extension and tail rigidity.

Video \#8 NSE-Cast 1-15: posterior paws clonus with whole body circling movements, tail rigidity, head and trunk retraction with small head version.

Video \#9 Cast-NSE 2-16: head and trunk retraction, posterior paws clonus above two paws, two movements similar to a hiccup, turns around, head and trunk extension and posterior paws clonus above two paws (animal seems dancing) Video \#10 Cast-NSE 3-24: strong head and trunk version to right side.

This material is available as part of the online article from https://www.scielo.br/j/bjb 